\title{
Wild Morchella conica Pers. from different origins: A comparative study of nutritional and bioactive properties
}

Vanessa Vieira $^{\mathrm{a}}$, Ângela Fernandes ${ }^{\mathrm{a}}$, Lillian Barros ${ }^{\mathrm{a},{ }^{*},}$, Jasmina Glamočlija ${ }^{\mathrm{b}}$, Ana Ćirić ${ }^{\mathrm{b}}$, Dejan Stojković $^{\mathrm{b}}$, Anabela Martins ${ }^{\mathrm{a}}$, Marina Soković $^{\mathrm{b}}$, Isabel C.F.R. Ferreira ${ }^{\mathrm{a},{ }^{*}}$

${ }^{a}$ Mountain Research Center(CIMO), ESA, Polytechnic Institute of Bragança, Campus de Santa Apolónia, Ap. 1172, 5301-855 Bragança, Portugal.

${ }^{\mathrm{b}}$ University of Belgrade, Department of Plant Physiology, Institute for Biological Research “Siniša Stankovič”, Bulevar Despota Stefana 142, 11000 Belgrade, Serbia

* Authors to whom correspondence should be addressed (Isabel C.F.R. Ferreira; e-mail: iferreira@ipb.pt; telephone +351-273-303219; fax +351-273-325405 and Lillian Barros; email: lillian@ipb.pt; telephone+351-273-303219; fax +351-273-325405).

Running title: Valorization of Wild Morchella conica Pers. from different origins 


\begin{abstract}
Background: Morchella conica Pers. is a species of fungus that belongs to the Morchellaceae family and was studied in order to obtain more information about this species, by comparing Portuguese and Serbian wild samples. Free sugars, fatty acids, tocopherols, organic and phenolic acids were analysed by chromatographic techniques. M. conica methanolic extracts were tested regarding antioxidant and antimicrobial properties. The absence of hepatoxicity was confirmed in porcine liver primary cells.

Results: The nutrition value varied between the two samples and the Serbian one gave the highest energy contribution and content in sugars, polyunsaturated fatty acids and phenolic compounds, while the Portuguese sample was richer in saturated and monounsaturated fatty acids, tocopherols and organic acids. In general, the Portuguese sample revealed the highest antioxidant potential (unless lipid peroxidation inhibition), while the Serbian one displayed higher antimicrobial activity. None of the samples revealed toxicity towards liver cells.
\end{abstract}

Conclusion: The present study provides new data concerning chemical characterization and bioactivity of Morchella conica Pers.

Keywords: Morchella conica; Edible mushroom; Nutrients/Non-nutrients; Antioxidant activity; Antimicrobial activity. 


\section{Introduction}

For several centuries wild mushrooms are part of the human diet due to their organoleptic characteristics (e.g., texture and flavour) and nutrition value. ${ }^{1}$ In fact, mushrooms have excellent nutritional value, low lipid content and large amounts of carbohydrates and proteins, also presenting many essential amino acids. ${ }^{2}$ Different species have also been valued for being an important source of fat-soluble vitamins (vitamins A, D, E and K). ${ }^{3}$

The abundance of bioactive compounds has sparked interest in this natural matrix. ${ }^{4}$ Examples of those compounds present in mushrooms are tocopherols, ${ }^{5}$ phenolic compounds $^{6}$ and organic acids, ${ }^{7}$ some of them also responsible for their nutraceutical potential. $^{8}$

Several mushroom species have been studied by the scientific community in order to develop new therapies, and the results have proven their bioactive properties. ${ }^{9}$ The nutraceuticals present in mushrooms have been related with their antioxidant properties ${ }^{4}$ and antimicrobial activity. ${ }^{10}$

The free radicals formation is associated with the normal metabolism of the organism. Nevertheless, the protection against free radicals can be increased by the introduction of antioxidants in the diet and subsequent role in the prevention of several diseases. ${ }^{11}$ In fact, antioxidants can help the endogenous defense system, playing an important role as potential protective agents, reducing oxidative damage. In this context, the possibility of including mushrooms, which contain significant amounts of bioactive phytochemicals, in our diet can provide desirable benefits to health, beyond basic nutrition. ${ }^{4}$ Furthermore, despite the wide diversity of antibacterial compounds, bacterial resistance to the antibiotic of first choice has dramatically increased. The association between multiresistant organisms and nosocomial infections raise the urgent need to find 
solutions. ${ }^{12}$ Therefore, the discovery of new antimicrobial compounds effective against pathogens resistant to conventional drugs is crucial, and mushrooms seem to be a possibility. $^{10}$

Morchella conica Pers. is a fungus belonging to the Ascomycota phylum. ${ }^{13}$ The head is distinctly conical in shape; the surface of head comprises a honeycomb of sharp ridges and deep pits and is rich brown in color. The texture is sponge-like; the head and stem is generally hollow. It grows generally on chalky soil in grassy woodlands, field margins ad roadside verges. ${ }^{14}$ There are reports on its bioactivity, including antioxidant ${ }^{15,16}$ and antimicrobial $^{14,17}$ activity. However, these studies do not include the chemical and nutritional characterization of the species.

In the present work, wild M. conica from two different origins (Portugal and Serbia) was evaluated regarding chemical composition and bioactivity. The chemical characterization was achieved through the evaluation of nutrients (macronutrients, free sugars, fatty acids and tocopherols) and non-nutrients (organic acids and phenolic acids); the bioactivity of its methanolic extract was evaluated in terms of antioxidant and antimicrobial potential, as was the confirmation of non-toxicity tested in a primary cell culture from porcine liver cells.

\section{Material and Methods}

\section{Sampling of mushroom species}

Morchella conica Pers.wild samples were collected in Bragança (Northeast of Portugal) and in Lipovica Forest, near Belgrade (Serbia), in October 2012. The authentications were done at the Polytechnic Institute of Bragança and at the Institute for Biological Research, Belgrade. Voucher specimens were deposited at herbarium of School of Agriculture of Polytechnic Institute of Bragança, Portugal, and at Fungal Collection 
Unit of the Mycological Laboratory, Department for Plant Physiology, Institute for Biological Research "Siniša Stanković”, Belgrade, Serbia, respectively.

The samples were immediately lyophilised (FreeZone 4.5, Labconco, Kansas City, MO, USA and LH Leybold, Lyovac GT2, Frenkendorf, Switzerland, respectively), reduced to a fine dried powder (20 mesh), mixed to obtain homogenate samples and stored in a desiccator, protected from light, until further analysis.

\section{Standards and Reagents}

Acetonitrile $99.9 \%, n$-hexane $95 \%$ and ethyl acetate $99.8 \%$ were of HPLC grade from Fisher Scientific (Lisbon, Portugal). The fatty acids methyl ester (FAME) reference standard mixture 37 (standard 47885-U) was purchased from Sigma (St. Louis, MO, USA), as also other individual fatty acid isomers, trolox (6-hydroxy-2,5,7,8tetramethylchroman-2-carboxylic acid), sugar (D(-)-fructose, $\mathrm{D}(-)$-mannitol, $\mathrm{D}(+)$ raffinosepentahydrate, and $\mathrm{D}(+)$-trehalose), tocopherol ( $\alpha-, \beta-, \gamma-$, and $\delta$-isoforms), organic acid (oxalic acid, quinic acid, and fumaric acid), cinnamic acid and phenolic compound (gallic acid, protocatechuic acid, $p$-hydroxybenzoic acid, $p$-coumaric acid) standards. Racemic tocol, $50 \mathrm{mg} / \mathrm{mL}$, was purchased from Matreya (PA, USA). 2,2Diphenyl-1-picrylhydrazyl (DPPH) was obtained from Alfa Aesar (Ward Hill, MA, USA). Dimethylsulfoxide (DMSO) (Merck KGaA, Germany) was used as a solvent in antimicrobial assays. Fetal bovine serum (FBS), Hank's balanced salt solution, nonessential amino acids solution $(2 \mathrm{mM})$, penicillin/streptomycin solution $(100 \mathrm{U} / \mathrm{mL}$ and $100 \mu \mathrm{g} / \mathrm{mL}$, respectively), DMEM medium was from Hyclone (Logan, Utah, USA). Acetic acid, ellipticine and sulforhodamine B (SRB) were from Sigma Chemical Co. (Saint Louis, MO, USA). Methanol and all other chemicals were of analytical grade and 
purchased from common sources. Water was treated in a Milli-Q water purification system (TGI Pure Water Systems, Greenville, SC, USA).

\section{Nutrients composition of $M$. conica fruiting bodies}

Nutritional value. The samples were analysed for the chemical composition (moisture, proteins, fat, carbohydrates and ash) using the standard procedures. ${ }^{18}$ The crude protein content $(\mathrm{N} \times 4.38)$ of the samples was estimated by the macro-Kjeldahl method; the crude fat was determined by extracting a known weight of powdered sample with petroleum ether, using a Soxhlet apparatus; the ash content was determined by incineration at $600 \pm 15^{\circ} \mathrm{C}$. Total carbohydrates were calculated by difference. Energy was calculated according to the following equation: Energy $(\mathrm{kcal})=4 \times(\mathrm{g}$ protein $+\mathrm{g}$ carbohydrate $)+9 \times(\mathrm{g}$ fat $) .{ }^{18}$

Free sugars. Free sugars were determined by a high performance liquid chromatograph (HPLC) system consisted of an integrated system with a pump (Knauer, Smartline system 1000, Berlin, Germany), degasser system (Smartline manager 5000) and an auto-sampler (AS-2057 Jasco, Easton, MD, USA), coupled to a refraction index detector (RI detector Knauer Smartline 2300) as previously described by the authors. ${ }^{19}$ The chromatographic separation was achieved with a Eurospher 100-5 $\mathrm{NH}_{2}$ column (5 $\mu \mathrm{m}, 250 \mathrm{~mm} \times 4.6 \mathrm{~mm}$ i.d., Knauer) operating at $35{ }^{\circ} \mathrm{C}(7971 \mathrm{R}$ Grace oven). The mobile phase was acetonitrile/deionized water, 70:30 $(v / v)$ at a flow rate of $1 \mathrm{~mL} \mathrm{~min}^{-1}$. Sugars identification was made by comparing the relative retention times of sample peaks with standards. Data were analyzed using Clarity 2.4 Software (DataApex, Prague, Czech Republic). Quantification was based on the RI signal response of each standard, using the internal standard (IS, raffinose) method and by using calibration 
curves obtained from the commercial standards of each compound. The results were expressed in $\mathrm{g} \mathrm{kg}^{-1}$ of dry weight.

Fatty acids. Fatty acids were determined after a trans-esterification procedure as described previously by the authors. ${ }^{19}$ The fatty acid profile was analysed using a gas chromatographer (DANI 1000, Contone, Switzerland) equipped with a split/splitless injector and a flame ionization detector (GC-FID, $260{ }^{\circ} \mathrm{C}$ ) and a Macherey-Nagel (Düren, Germany) column (50\% cyanopropyl-methyl-50\% phenylmethylpolysiloxane, $30 \mathrm{~m} \times 0.32 \mathrm{~mm}$ i.d. $\times 0.25 \mu \mathrm{m} \mathrm{d}_{\mathrm{f}}$ ). The oven temperature program was as follows: the initial temperature of the column was $50^{\circ} \mathrm{C}$, held for $2 \mathrm{~min}$, then a $30^{\circ} \mathrm{C} / \mathrm{min}$ ramp to $125{ }^{\circ} \mathrm{C}, 5{ }^{\circ} \mathrm{C} / \mathrm{min}$ ramp to $160{ }^{\circ} \mathrm{C}, 20{ }^{\circ} \mathrm{C} / \mathrm{min}$ ramp to $180{ }^{\circ} \mathrm{C}, 3{ }^{\circ} \mathrm{C} / \mathrm{min}$ ramp to $200{ }^{\circ} \mathrm{C}$, $20{ }^{\circ} \mathrm{C} / \mathrm{min}$ ramp to $220^{\circ} \mathrm{C}$ and held for $15 \mathrm{~min}$. The carrier gas (hydrogen) flow-rate was $4.0 \mathrm{~mL} / \mathrm{min}(0.61 \mathrm{bar})$, measured at $50^{\circ} \mathrm{C}$. Split injection $(1: 40)$ was carried out at 250 ${ }^{\circ} \mathrm{C}$.). Fatty acids identification was made by comparing the relative retention times of FAME peaks from samples with standards. The results were recorded and processed using Clarity 4.0.1.7 Software (DataApex, Prague, Czech Republic) and expressed in relative percentage of each fatty acid.

Tocopherols. Tocopherols were determined following a procedure previously optimized and described by the authors. ${ }^{5}$ Analysis was performed by HPLC (equipment described above), and a fluorescence detector (FP-2020; Jasco) programmed for excitation at 290 $\mathrm{nm}$ and emission at $330 \mathrm{~nm}$. The chromatographic separation was achieved with a Polyamide II normal-phase column $(5 \mathrm{~mm}, 250 \mathrm{~mm} \times 4.6 \mathrm{~mm}$ i.d., YMC Waters $)$, operating at $35^{\circ} \mathrm{C}$. The mobile phase used was a mixture of n-hexane and ethyl acetate $(70: 30, v / v)$ at a flow rate of $1 \mathrm{~mL} \mathrm{~min}^{-1}$. The compounds were identified by 
chromatographic comparisons with authentic standards. Quantification was based on the fluorescence signal response of each standard, using the IS (tocol) method and by using calibration curves obtained from commercial standards of each compound. The results were expressed in $\mu \mathrm{g} \mathrm{kg}^{-1}$ of dry weight.

\section{Non-nutrients composition of $M$. conica fruiting bodies}

Organic acids. Organic acids were determined by ultra-fast liquid chromatography (UFLC, Shimadzu 20A series, Shimadzu Corporation, Kyoto, Japan) coupled with a photodiode array detector (PDA) as previously optimized and described by the authors. ${ }^{7}$ Separation was achieved on a SphereClone (Phenomenex) reverse phase $\mathrm{C}_{18}$ column (5 $\mu \mathrm{m}, 250 \mathrm{~mm} \times 4.6 \mathrm{~mm}$ i.d) thermostatted at $35^{\circ} \mathrm{C}$. The elution was performed with sulphuric acid $3.6 \mathrm{mM}$ using a flow rate of $0.8 \mathrm{~mL} \mathrm{~min}^{-1}$. Detection was carried out in a PDA, using $215 \mathrm{~nm}$ as preferred wavelength. The organic acids were quantified by comparison of the area of their peaks recorded at $215 \mathrm{~nm}$ with calibration curves obtained from commercial standards of each compound: oxalic acid $\left(y=9 \times 10^{6} x+\right.$ $\left.377946 ; R^{2}=0.994\right)$; quinic acid $\left(y=612327 x+16563 ; R^{2}=1\right)$ and fumaric acid $(y=$ $\left.148083 x+96092, R^{2}=1\right)$. The results were expressed in $\mathrm{g} \mathrm{kg}^{-1}$ of dry weight.

Phenolic acids and related compounds. Phenolic acids determination was performed using a Shimadzu 20A series ultra-fast liquid chromatograph (UFLC, Shimadzu, equipment described above) as previously described by Stojković et al. ${ }^{20}$ Separation was achieved on an Aqua $(3 \mu \mathrm{m}, 150 \mathrm{~mm}$ x $4.6 \mathrm{~mm}$ i.d., Phenomenex, Torrance, CA, USA) reverse phase $\mathrm{C}_{18}$ column $\left(5 \mu \mathrm{m}, 250 \mathrm{~mm} \times 4.6 \mathrm{~mm}\right.$ i.d.) thermostatted at $35^{\circ} \mathrm{C}$. The mobile phase was: (A) $0.1 \%$ formic acid in water, (B) $100 \%$ HPLC-grade acetonitrile. The elution gradient established was $10 \%$ A to $15 \%$ B over 5 min, $15-25 \%$ 
$\mathrm{A}$ in $\mathrm{B}$ over $5 \mathrm{~min}, 25-35 \% \mathrm{~A}$ in $\mathrm{B}$ over $10 \mathrm{~min}$, isocratic $50 \% \mathrm{~B}$ for $10 \mathrm{~min}$, and reequilibration of the column, using a flow rate of $0.5 \mathrm{ml} \mathrm{min}^{-1}$. The phenolic compounds were characterized according to their UV and mass spectra and retention times, and comparison with authentic standards when available. The phenolic compounds were quantified by comparison of the area of their peaks recorded at 280 and $370 \mathrm{~nm}$ with calibration curves obtained from commercial standards of each compound: gallic acid $\left(y=224587 x-129097 ; R^{2}=1\right) ;$ protocatechuic acid $\left(y=116749 x-38733 ; R^{2}=1\right), p$ hydroxybenzoic acid $\left(y=164204 x+12917 ; R^{2}=1\right), p$-coumaric acid $(y=511958 x-$ $\left.1 \times 10^{6} ; R^{2}=0.992\right)$, cinammic acid $\left(y=863668 x-884517 ; R^{2}=0.999\right)$. The results were expressed in $\mathrm{mg} \mathrm{kg}^{-1}$ of dry weight.

\section{Bioactivity of $M$. conica methanolic extract}

Extracts preparation. Each lyophilized sample $(1 \mathrm{~g})$ was extracted by stirring with 40 $\mathrm{mL}$ of methanol for $1 \mathrm{~h}$ and subsequently filtered through Whatman No. 4 paper. The residue was then extracted with $20 \mathrm{~mL}$ of methanol for $1 \mathrm{~h}$. The combined methanolic extracts were evaporated at $40^{\circ} \mathrm{C}$ (rotary evaporator Büchi R-210, Flawil, Switzerland) to dryness and re-dissolved in a) methanol for antioxidant activity assays (20 mg mL $\left.\mathrm{m}^{-1}\right)$, b) $5 \%$ solution of DMSO in distilled water for antimicrobial activity assays (100 mg $\left.\mathrm{mL}^{-1}\right)$, and $c$ ) distillated water for the toxicity assay in porcine liver primary cells $(8 \mathrm{mg}$ $\left.\mathrm{mL}^{-1}\right) .^{20}$

Antioxidant activity assays. Successive dilutions (5, 2.5, 1.25, 0.625 and $0.3125 \mathrm{mg} \mathrm{mL}^{-}$ ${ }^{1}$ ) were made from the stock solution and submitted to the in vitro assays already described by Heleno et al. ${ }^{5}$, to evaluate the antioxidant activity of the samples. The sample concentrations $\left(\mathrm{mg} \mathrm{mL}^{-1}\right)$ providing $50 \%$ of antioxidant activity or 0.5 of 
absorbance $\left(\mathrm{EC}_{50}\right)$ were calculated from the graphs of antioxidant activity percentages (DPPH, $\beta$-carotene/linoleate and TBARS assays) or absorbance at $690 \mathrm{~nm}$ (ferricyanide/Prussian blue assay) against sample concentrations. Trolox was used as a positive control.

Folin-Ciocalteu assay. One of the extract solutions $\left(5 \mathrm{mg} \mathrm{mL}^{-1} ; 1 \mathrm{~mL}\right)$ was mixed with Folin-Ciocalteu reagent $(5 \mathrm{~mL}$, previously diluted with water $1: 10, \mathrm{v} / \mathrm{v})$ and sodium carbonate $\left(75 \mathrm{~g} \mathrm{~L}^{-1}, 4 \mathrm{~mL}\right)$. The tubes were vortex mixed for $15 \mathrm{~s}$ and allowed to stand for $30 \mathrm{~min}$ at $40{ }^{\circ} \mathrm{C}$ for color development. Absorbance was then measured at $765 \mathrm{~nm}$ (Analytikjena spectrophotometer; Jena, Germany). Gallic acid was used to obtain the standard curve and the reduction of the Folin-Ciocalteu reagent by the samples was expressed as mg of gallic acid equivalents (GAE) per g of extract. ${ }^{5}$

Ferricyanide/Prussian blue assay. The extract solutions with different concentrations $(0.5 \mathrm{~mL})$ were mixed with sodium phosphate buffer $\left(200 \mathrm{mmol} \mathrm{L}^{-1}, \mathrm{pH} 6.6,0.5 \mathrm{~mL}\right)$ and potassium ferricyanide $(1 \% \mathrm{w} / \mathrm{v}, 0.5 \mathrm{~mL})$. The mixture was incubated at $50{ }^{\circ} \mathrm{C}$ for $20 \mathrm{~min}$, and trichloroacetic acid $(10 \% \mathrm{w} / \mathrm{v}, 0.5 \mathrm{~mL})$ was added. The mixture $(0.8 \mathrm{~mL})$ was poured in the 48 wells plate, the same with deionized water $(0.8 \mathrm{~mL})$ and ferric chloride $(0.1 \% w / v, 0.16 \mathrm{~mL})$, and the absorbance was measured at $690 \mathrm{~nm}$ in ELX800Microplate Reader (Bio-Tek Instruments, Inc; Winooski, VT, USA). ${ }^{5}$

DPPH radical-scavenging activity assay. This methodology was performed using the Microplate Reader mentioned above. The reaction mixture on 96 well plate consisted of a solution by the well of the extract solutions with different concentrations ( $30 \mu \mathrm{L})$ and methanolic solution $(270 \mu \mathrm{L})$ containing DPPH radicals $\left(6 \times 10^{-5} \mathrm{~mol} \mathrm{~L}^{-1}\right)$. The mixture was left to stand for $30 \mathrm{~min}$ in the dark, and the absorption was measured at $515 \mathrm{~nm}$. The radical scavenging activity (RSA) was calculated as a percentage of DPPH discoloration using the equation: $\% \mathrm{RSA}=\left[\left(\mathrm{A}_{\mathrm{DPPH}}-\mathrm{A}_{\mathrm{S}}\right) / \mathrm{A}_{\mathrm{DPPH}}\right] \times 100$, where $\mathrm{A}_{\mathrm{S}}$ is the 
absorbance of the solution containing the sample, and $A_{\mathrm{DPPH}}$ is the absorbance of the DPPH solution. ${ }^{5}$

Inhibition of $\beta$-carotene bleaching or $\beta$-carotene/linoleate assay. A solution of $\beta$ carotene was prepared by dissolving $\beta$-carotene $(2 \mathrm{mg})$ in chloroform $(10 \mathrm{~mL})$. Two milliliters of this solution were pipetted into a round-bottom flask. The chloroform was removed at $40{ }^{\circ} \mathrm{C}$ under vacuum and linoleic acid $(40 \mathrm{mg})$, Tween 80 emulsifier (400 $\mathrm{mg})$, and distilled water $(100 \mathrm{~mL})$ were added to the flask with vigorous shaking. Aliquots $(4.8 \mathrm{~mL})$ of this emulsion were transferred into test tubes containing extract solutions with different concentrations $(0.2 \mathrm{~mL})$. The tubes were shaken and incubated at $50{ }^{\circ} \mathrm{C}$ in a water bath. As soon as the emulsion was added to each tube, the zero time absorbance was measured at $470 \mathrm{~nm}$. $\beta$-Carotene bleaching inhibition was calculated using the following equation: (Absorbance after $2 \mathrm{~h}$ of assay/ initial absorbance) $\times 100{ }^{5}$

Thiobarbituric acid reactive substances (TBARS) assay. Porcine (Sus scrofa) brains were obtained from official slaughtered animals, dissected, and homogenized with Polytron in an ice cold Tris- $\mathrm{HCl}$ buffer $(20 \mathrm{mM}, \mathrm{pH} 7.4)$ to produce a $1: 2 w / v$ brain tissue homogenate which was centrifuged at $3000 \mathrm{~g}$ for10 min. An aliquot $(100 \mu \mathrm{L})$ of the supernatant was incubated with the different concentrations of the sample solutions $(200 \mu \mathrm{L})$ in the presence of $\mathrm{FeSO}_{4}(10 \mathrm{mM} ; 100 \mu \mathrm{L})$ and ascorbic acid $(0.1 \mathrm{mM} ; 100$ $\mu \mathrm{L})$ at $37{ }^{\circ} \mathrm{C}$ for $1 \mathrm{~h}$. The reaction was stopped by the addition of trichloroacetic acid $(28 \% w / v, 500 \mu \mathrm{L})$, followed by thiobarbituric acid (TBA, $2 \%, w / v, 380 \mu \mathrm{L})$, and the mixture was then heated at $80{ }^{\circ} \mathrm{C}$ for $20 \mathrm{~min}$. After centrifugation at $3000 \mathrm{~g}$ for $10 \mathrm{~min}$ to remove the precipitated protein, the color intensity of the malondialdehyde (MDA)TBA complex in the supernatant was measured by its absorbance at $532 \mathrm{~nm}$. The inhibition ratio (\%) was calculated using the following formula: Inhibition ratio 
$(\%)=[(\mathrm{A}-\mathrm{B}) / \mathrm{A}] \times 100 \%$, where $\mathrm{A}$ and $\mathrm{B}$ were the absorbance of the control and the sample solution, respectively. ${ }^{5}$

Antibacterial activity assays. The following Gram-negative bacteria: Escherichia coli (ATCC 35210), Pseudomonas aeruginosa (ATCC 27853), Salmonella typhimurium (ATCC 13311), Enterobacter cloacae (ATCC 35030), and Gram-positive bacteria: Staphylococcus aureus (ATCC 6538), Bacillus cereus (clinical isolate), Micrococcus flavus (ATCC 10240), and Listeria monocytogenes (NCTC 7973) were used. The microorganisms were obtained from the Mycological laboratory, Department of Plant Physiology, Institute for biological research "Siniša Stanković”, University of Belgrade, Serbia.

The minimum inhibitory (MIC) and minimum bactericidal (MBC) concentrations were determined by the microdilution method. ${ }^{21}$ Fresh overnight culture of bacteria was adjusted by the spectrophotometer to a concentration of $1 \times 10^{5} \mathrm{CFU} \mathrm{mL} \mathrm{m}^{-1}$. The requested $\mathrm{CFU} \mathrm{mL} \mathrm{m}^{-1}$ corresponded to a bacterial suspension determined in a spectrophotometer at $625 \mathrm{~nm}$ (OD625). Dilutions of inocula were cultured on solid medium to verify the absence of contamination and check the validity of the inoculum. Different solvent dilutions of methanolic extract were carried out over the wells containing $100 \mu \mathrm{L}$ of Tryptic Soy Broth (TSB) and afterwards, $10 \mu \mathrm{L}$ of inoculum was added to all the wells. The microplates were incubated for $24 \mathrm{~h}$ at $37^{\circ} \mathrm{C}$. The MIC of the samples was detected following the addition of $40 \mu \mathrm{L}$ of iodonitrotetrazolium chloride (INT) $\left(0.2 \mathrm{mg} \mathrm{mL}^{-1}\right)$ and incubation at $37^{\circ} \mathrm{C}$ for $30 \mathrm{~min}$. The lowest concentration that produced a significant inhibition (around 50\%) of the growth of the bacteria in comparison with the positive control was identified as the MIC. The minimum inhibitory concentrations (MICs) obtained from the susceptibility testing of various bacteria to tested extracts were 
determined also by a colorimetric microbial viability assay based on reduction of a INT color and compared with positive control for each bacterial strains. ${ }^{22,23}$ MBC was determined by serial sub-cultivation of $10 \mu \mathrm{L}$ into microplates containing $100 \mu \mathrm{L}$ of TSB. The lowest concentration that shows no growth after this sub-culturing was read as the MBC. Standard drugs, namely streptomycin and ampicillin were used as positive controls. 5\% DMSO was used as negative control. Samples were tested in duplicates and experiments were repeated three times.

Antifungal activity assays. For the antifungal bioassays, the following microfungi were used: Aspergillus ochraceus (ATCC 12066), Aspergillus versicolor (ATCC 11730), Aspergillus niger (ATCC 6275), Trichoderma viride (IAM 5061), Penicillium aurantiogriseum (food isolate). The organisms were obtained from the Mycological Laboratory, Department of Plant Physiology, Institute for Biological Research "Siniša Stanković", Belgrade, Serbia. The micromycetes were maintained on malt agar (MA) and the cultures were stored at $4^{\circ} \mathrm{C}$ and sub-cultured once a month. ${ }^{24}$

The fungal spores were washed from the surface of agar plates with sterile $0.85 \%$ saline containing $0.1 \%$ Tween $80(v / v)$. The spore suspension was adjusted with sterile saline to a concentration of approximately $1.0 \times 10^{5}$ in a final volume of $100 \mu \mathrm{L}$ well ${ }^{-1}$. The inocula were stored at $4{ }^{\circ} \mathrm{C}$ for further use. Dilutions of the inocula were cultured on solid MA to verify the absence of contamination and to check the validity of the inoculum.

Minimum inhibitory concentrations (MICs) determination was performed by a serial dilution technique using 96-well microtitre plates. The investigated extract was dissolved in 5\% solution of DMSO and added to broth malt medium with fungal inoculum. The microplates were incubated for $72 \mathrm{~h}$ at $28^{\circ} \mathrm{C}$. The lowest concentrations 
without visible growth (at the binocular microscope) were defined as MIC. The minimum fungicidal concentrations (MFCs) were determined by serial subcultivation of $2 \mu \mathrm{L}$ in microtitre plates containing $100 \mu \mathrm{L}$ of malt broth per well and further incubation for $72 \mathrm{~h}$ at $28{ }^{\circ} \mathrm{C}$. The lowest concentration with no visible growth was defined as the MFC, indicating 99.5\% killing of the original inoculum. 5\% DMSO was used as a negative control, while bifonazole and ketokonazole were used as positive controls. Samples were tested in duplicates and experiments were repeated three times. Toxicity for liver cells assay. A cell culture was prepared from a freshly harvested porcine liver obtained from a local slaughter house. It was designated as PLP2. Briefly, the liver tissues were rinsed in Hank's balanced salt solution containing $100 \mathrm{U} \mathrm{mL}^{-1}$ penicillin and $100 \mu \mathrm{g} \mathrm{mL}^{-1}$ streptomycin and divided into $1 \times 1 \mathrm{~mm}^{3}$ explants. Some of these explants were placed in $25 \mathrm{~cm}^{3}$ tissue flasks in DMEM supplemented with $10 \%$ fetal bovine serum, $2 \mathrm{mM}$ nonessential amino acids and $100 \mathrm{U} \mathrm{mL}^{-1}$ penicillin, 100 $\mathrm{mg} / \mathrm{mL}$ streptomycin and incubated at $37^{\circ} \mathrm{C}$ with a humidified atmosphere containing $5 \% \mathrm{CO}_{2}$. The medium was changed every 2 days. Cultivation of the cells was continued with direct monitoring every 2-3 days using a phase contrast microscope. Before confluence, cells were sub-cultured and plated in 96-well plates at a density of $1.0 \times 10^{4}$ cells well ${ }^{-1}$, and cultivated in DMEM medium with $10 \% \mathrm{FBS}, 100 \mathrm{U} \mathrm{mL}^{-1}$ penicillin and $100 \mu \mathrm{g} \mathrm{mL}{ }^{-1}$ streptomycin. ${ }^{20}$ Cells were treated for $48 \mathrm{~h}$ with the different diluted sample solutions and the same procedure described in the previous section for SRB assay was followed. The results were expressed in $\mathrm{GI}_{50}$ values (sample concentration that inhibited $50 \%$ of the net cell growth). Ellipticine was used as positive control.

\section{Statistical analysis}


Three samples were used and all the assays were carried out in triplicate. The results are expressed as mean values and standard deviation (SD). Nutrients and non-nutrients composition and antioxidant activity results were compared by means of a Student's $t$ test to determine the significant difference among samples, with $p=0.05$. The results obtained for antimicrobial activity were analyzed using one-way analysis of variance (ANOVA) followed by Tukey's HSD Test with $p=0.05$. These analysis were carried out using SPSS v. 22.0 program (IBM Corp., Armonk, NY, USA).

\section{Results and discussion}

\section{Composition in nutrients and non-nutrients}

The composition in nutrients of $M$. conica samples is presented in Table 1. There were no significant differences concerning fat content. The Serbian sample showed the highest level of proteins and carbohydrates. However, the Portuguese sample had the highest levels of ash. The energetic contribution of the Serbian sample was also superior. Regarding free sugars composition, fructose was detected in both samples and in the same concentration (Table 1). Mannitol and trehalose, also very common in mushrooms, were detected in both samples (Figure 1A), and the Serbian one revealed the highest content in total free sugars. Mannitol, a sugar alcohol, has half calories of sugar and is half as sweet, and because it is poorly absorbed by the body, it does not raise insulin levels as much as sugar and also does not promote tooth decay. This sugar is also important in providing support and expansion of the fruiting body. ${ }^{25}$

The fatty acids quantified in higher amounts in $M$. conica (Table 1) were palmitic acid (C16:0), stearic acid (C18:0), oleic acid (C18:1n9) and linoleic acid (C18:2n6), being the saturated fatty acids (SFA; palmitic and stearic acids) present in lower amounts. Oleic acid (monounsaturated fatty acid- MUFA) was found in higher percentages in the 
Portuguese sample; linoleic acid (polyunsaturated fatty acid- PUFA) was the main fatty acid presented in both samples (Figure 1B). The Portuguese sample was richer in SFA and MUFA, however Serbian sample presented the highest level of PUFA. PUFA, especially the n-3 fatty acids family, are claimed to exert a protective effect against the development of cardiovascular and inflammatory diseases. ${ }^{26,27}$ Particularly, linoleic acid plays an important role in preventing cardiovascular diseases in adults, promoting the brain and retina development in infants ${ }^{28-30}$ or preventing DNA damage. ${ }^{31}$

$\alpha$-Tocopherol isoform was detected in both samples and the Portuguese one presented the highest levels (Table 1). On the other hand, $\beta$-tocopherol was only present in the Portuguese sample and $\delta$-tocopherol in the Serbian one. It was the Portuguese sample that revealed the highest content of total tocopherols. The differences found could be explained by the fact that tocopherols are molecules that are very easily oxidised either during the fruiting body growth or in the extraction procedures. Therefore, it is necessary to consider all these aspects, as also perform certain precautions during the extraction methodologies. Vitamin E is found in large amounts in lipids, and some evidence suggest that this vitamin prevents or minimizes the damage caused by free radicals associated with specific diseases, including cancer, arthritis, cataracts and aging. ${ }^{32,33}$ Recent evidences suggest that vitamin E reduced Alzheimer's disease and dementia $^{34,35}$ and has neuroprotective action against cisplatin peripheral neurotoxicity. ${ }^{36}$ Vitamin $\mathrm{E}$ has the ability to prevent the spread of chain reactions induced by free radicals in biological membranes. ${ }^{37}$

Regarding $M$. conica organic acids profile, it was possible to quantify three different compounds (Table 2), namely oxalic, quinic, and fumaric acids (Figure 1C). The wild mushroom from Portugal was the one that revealed the highest concentration in oxalic and fumaric acids, while the Serbian sample presented the highest quinic acid. The 
Portuguese sample showed the highest content in total organic acids. Concerning phenolic acids, the studied samples revealed the presence of gallic, protocatechuic, $p$ hydroxybenzoic and $p$-coumaric acids, as also the related compound cinnamic acid (Table 2). Gallic and $p$-hydroxybenzoic acids were only present in the Serbian wild sample. Protocatechuic and $p$-coumaric acids were found in highest concentrations in the Portuguese sample. The related compound cinnamic acid was only found in the Serbian sample. Puttaraju et al. ${ }^{15}$ did not found $p$-hydroxybenzoic and cinnamic acids in an Indian sample, but the research group found six other compounds: tannic, gentisic, vanillic, syringic, caffeic and ferulic acids. Nevertheless, these authors applied a slightly different extraction methodologies and the method applied to identify the phenolic compounds also presented differences in the elution procedure, which could result in the differences found. Analyzing these results we can conclude that the wild sample from Serbia was richer in phenolic acids comparing with the Portuguese one. Phenolic compounds, namely phenolic acids, are among the most potent and therapeutically useful bioactive substances, providing health benefits associated with reduced risk of chronic and degenerative diseases. ${ }^{38-40}$

It must be noted that the differences found in the chemical composition among samples of different origins might be related to a diversity of factors such as, climatic conditions and soil composition. According to the results it seems that Serbian species grown under higher stress with an increase in the production of secondary metabolites namely, phenolic compounds. Furthermore, differences found in individual compounds, can also be attributed to different extraction and/or analysis methodologies.

\section{Bioactive properties}


Analyzing the results of the antioxidant potential (Table 3), M. conica samples (methanolic extracts) from Portugal revealed the highest reducing power evaluated through the Folin-Ciocalteu and Ferricyanide/Prussian blue assays. Total phenolics content, measured by Folin-Ciocalteu assay, were different from other results from Turkey $\left(25.38 \mu \mathrm{g} \mathrm{GAE} \mathrm{mg}^{-1}\right.$ extract $^{16}$ and $20.64 \mathrm{mg} \mathrm{GAE} \mathrm{g}^{-1}$ extract $\left.^{17}\right)$. Both extracts of samples from Turkey had lower amounts of total phenolics when compared to Portuguese and Serbian wild samples. Nevertheless, Turkoglu et al. ${ }^{14}$ described the total phenolic amount of $M$. conica as $41.93 \mu \mathrm{g} \mathrm{mg}{ }^{-1}$ pyrocatechol equivalents in the ethanolic extract. Puttaraju et al. ${ }^{15}$ studied water and methanolic extracts of $M$. conica from India, revealing the total content in phenolics $\left(16.9 \pm 0.01 \mathrm{mg} \mathrm{g}^{-1}\right.$ water extract and $4.6 \pm 0.01 \mathrm{mg} \mathrm{g} \mathrm{g}^{-1}$ methanolic extract) and the reducing power ability though Ferricyanide/Prussian blue assay $\left(3.90 \pm 0.25 \mathrm{mg}\right.$ of GAE g ${ }^{-1}$ of sample water extract and $8.62 \pm 0.38 \mathrm{mg}$ of GAE $\mathrm{g}^{-1}$ methanolic extract). Gursoy et al. ${ }^{16}$, studied the reducing power of methanolic extracts of $M$. conica presenting their absorbance at $700 \mathrm{~nm}$. The Portuguese sample also revealed a higher radical scavenging activity, presenting a lower $\mathrm{EC}_{50}$ value for the DPPH assay. This activity was also previously reported for $M$. conica by Turkoglu et al. ${ }^{14}$ for ethanolic extract $\left(\mathrm{EC}_{50}=267 \mu \mathrm{g} \mathrm{mL}{ }^{-1}\right)$ and Puttaraju et al. ${ }^{15}$, for water and methanolic extracts $\left(\mathrm{EC}_{50}=5.00 \pm 0.31\right.$ and $1.60 \pm 0.33 \mathrm{mg} \mathrm{mL}^{-1}$, respectively) obtained from Indian samples. Furthermore, Gursoy et al. ${ }^{16}$ described $43 \%$ for DPPH inhibition by a methanolic extract of $M$. conica at $2 \mathrm{mg} \mathrm{mL}^{-1}$, while Ozturk et al. ${ }^{17}$ reported $44 \%$ of inhibition by ethanolic extract of $M$. conica at $20 \mathrm{mg} \mathrm{mL}^{-1}$. Therefore, Indian samples ${ }^{15}$ showed higher activity than the samples studied herein. However, the sample from Turkey ${ }^{14}$ gave the highest antioxidant activity of all. The Serbian sample showed highest lipid peroxidation inhibition, once it presented the lowest $\mathrm{EC}_{50}$ values for $\beta$-carotene/linoleate and TBARS assays. Turkoglu et al. ${ }^{14}$, demonstrated that 
approximately $40 \mu \mathrm{g} \mathrm{mL} \mathrm{mL}^{-1}$ promoted $50 \%$ of inhibition of oxidation in $\beta$ carotene/linoleate assay. Puttaraju et al. ${ }^{15}$ also studied the inhibition of lipid peroxidation by TBARS assay. Gursoy et al. ${ }^{16}$ showed that $0.5 \mathrm{mg} \mathrm{mL}^{-1}$ of $M$. conica extract inhibited $82 \%$ of lipid peroxidation measured through $\beta$-carotene-linoleate acid method. When comparing with the results of the cited authors, our samples revealed lower inhibition of lipid peroxidation.

Methanolic extracts of the Portuguese and Serbian wild M. conica samples exhibited antibacterial activity against all bacteria tested (Table 4). Both extracts showed highest antibacterial potential against Bacillus cereus; in addiction the Portuguese sample showed the same results of MIC and MBC against Pseudomonas aeruginosa and Salmonella typhimurium. The lowest antibacterial activity of the two samples was achieved against Escherichia coli and Enterobacter cloacae; the Serbian sample also presented the same results against Micrococcus flavus. Methanolic extract obtained from the Portuguese sample, in general, showed higher antibacterial potential than extract prepared from the Serbian sample. Both extracts possessed the same activity against Listeria monocytogenes, and in the case of Pseudomonas aeruginosa, Portuguese sample possessed higher activity than the commercial antibiotic ampicillin. Regarding the antifungal activity (Table 4), the highest antifungal potential was verified for Trichoderma viride. The lowest antifungal activity was achieved towards Aspergillus versicolor, Penicillium aurantiogriseum and Aspergillus ochraceus for the for the both samples. In general, the Portuguese wild sample showed the highest antifungal activity. Moreover, this sample was more efficient against Trichoderma viride than ketoconazole (by comparison of MICs). There are few studies about antimicrobial activity of $M$. conica, and all of them used agar-well diffusion method. Turkoglu et al. ${ }^{14}$, described no inhibition of the ethanolic extract against Pseudomonas 
aeruginosa and Escherichia coli. Ozturk et al. ${ }^{17}$ also studied Pseudomonas aeruginosa, Escherichia coli and Bacillus cereus inhibition, without presenting any positive results from $M$. conica ethanolic extracts. However, both of our samples presented activity against these three species. Presumably, many factors influence accumulation of bioactive compounds in mushrooms, but water availability, as well as exogenous environmental factors, exposure to various light sources and the presence of fungal or predatory pressures, cause the changes in dynamics of bioactive molecules biosynthesis and, therefore, cause the different pharmacological potential of the investigated samples.

As the methanolic extracts displayed antioxidant and antimicrobial activity, it was important to guarantee their absence of cytotoxicity against liver cells, which are considered the best in vitro model for studies of human cytotoxicity. The studied samples revealed no toxicity in liver primary culture PLP2, once the $\mathrm{GI}_{50}$ values obtained were higher than the highest concentration tested.

\section{Conclusions}

Overall, the Serbian sample revealed the highest content in free sugars, PUFA and phenolic compounds, while the Portuguese sample revealed higher concentrations of SFA, MUFA, tocopherols and organic acids. The methanolic extract of the Portuguese sample revealed the highest antioxidant potential (with exception towards lipid peroxidation inhibition), while the Serbian one showed the highest antimicrobial activity. Both extracts are considered safe since they did not show toxicity in porcine liver primary cells. This study provides new data concerning chemical characterization and bioactivity of Morchella conica Pers. Although with different profiles, Portuguese 
and Serbian wild samples proved to be a good source of a wide range of nutrients and bioactive molecules.

\section{Acknowledgements}

The authors are grateful to Fundação para a Ciência e Tecnologia (FCT, Portugal) and COMPETE/QREN/EU for financial support to this work (research project PTDC/AGRALI/110062/2009 and BPD/4609/2008 to L. Barros) and to CIMO (strategic project PEst-OE/AGR/UI0690/2011). The authors also thank Serbian Ministry of Education, Science and Technological Development for financial support (grant number 173032).

\section{References}

1 Kalac P, Chemical composition and nutritional value of European species of wild growing mushrooms: A review. Food Chem 113:9-16 (2009).

2 Furlani RPZ, Godoy HT, Nutritional value of edible mushrooms: a revision. Revista do Instituto Adolfo Lutz 64:149-154 (2005).

3 Barros L, Baptista P, Correia DM, Casal S, Oliveira B, Ferreira ICFR, Fatty acid and sugar compositions, and nutritional value of five wild edible mushrooms from Northeast Portugal. Food Chem 105:140-145 (2007).

4 Ferreira ICFR, Barros L, Abreu RMV, Antioxidants in wild mushrooms. Curr Med Chem 16:1543-1560 (2009).

5 Heleno SA, Barros L, Sousa MJ, Martins A, Ferreira ICFR, Tocopherols composition of Portuguese wild mushrooms with antioxidant capacity. Food Chem 119:1443-1450 (2010). 
6 Vaz JA, Barros L, Martins A, Morais JS, Vasconcelos MH, Ferreira ICFR, Phenolic profile of seventeen Portuguese wild mushrooms. LWT 44:343-346 (2011).

7 Barros L, Pereira C, Ferreira ICFR, Optimized analysis of organic acids in edible mushrooms from Portugal by Ultra Fast Liquid Chromatography and Photodiode Array Detection. Food Anal Method 6:309-316 (2013).

8 Barros L, Cruz T, Baptista P, Estevinho LM, Ferreira ICFR, Wild and commercial mushrooms as source of nutrients and nutraceuticals. Food Chem Toxicol 46:2742-2747 (2008).

9 Lindequist U, Niedermeyer THJ, Julich WD, The pharmacological potential of mushrooms. Evidence-Based Complement Alternative Med 2:285-299 (2005).

10 Alves MJ, Ferreira ICFR, Dias J, Teixeira V, Martins A, Pintado M, A review on antimicrobial activity of mushroom (Basidiomycetes) extracts and isolated compounds. Planta Medica 78:1707-1718 (2012).

11 Alam N, Bristi NJ, Rafiquzzaman Md, Review on in vivo and in vitro methods evaluation of antioxidant activity. Saudi Pharm J 21:143-152 (2013).

12 Pittet D, Infection control and quality health care in the new millennium. Am J Inf Control 33:258-267 (2005).

13 Masaphy S, Zabari, L, Observations on post-fire black morel ascocarp development in an Israeli burnt forest site and their preferred micro-sites. Fungal Ecology 6:316-318 (2013).

14 Turkoglu A, Kivrak I, Mercan N, Duru ME, Gezer K, Turkoglu H, Antioxidant and antimicrobial activities of Morchella conica Pers. Afri J Biotechn 5:11461150 (2006). 
15 Puttaraju NG, Venkateshaiah SU, Dharmesh SM, Urs SMN, Somasundaram R, Antioxidant activity of indigenous edible mushrooms. J Agric Food Chem 54:9764-9772 (2006).

16 Gursoy N, Sarikurkcu C, Cengiz M, Solak MH, Antioxidant activities, metal contents, total phenolics and flavonoids of seven Morchella species. Food Chem Toxicol 47:2381-2388 (2009).

17 Ozturk I, Sahan S, Sahin U, Ekici L, Sagdic O, Bioactivity and mineral contents of wild-grown edible Morchella conica in the Mediterranean Region. J für Verbraucherschutz Lebensmittelsicherheit 5:453-457 (2010).

18 AOAC, Official methods of analysis. Association of Official Analytical Chemists, 16th ed., Arlington VA, USA (1995).

19 Heleno SA, Barros L, Sousa MJ, Martins A, Ferreira ICFR, Study and characterization of selected nutrients in wild mushrooms from Portugal by gas chromatography and high performance liquid chromatography. Microchem $J$ 93:195-199 (2009).

20 Stojković DS, Barros L, Calhelha RC, Glamočlija J, Ćirić A, Van Griensven LJLD, Soković M, Ferreira ICFR, A detailed comparative study between chemical and bioactive properties of Ganoderma lucidum from different origins. Int J Food Sci Nutr 65:42-47(2014).

21 Espinel-Ingroff A, Comparation of the E-test with the NCCLS M38-P method for antifungal susceptibility testing of common and emerging pathogenic filamentous fungi. J Clin Microbiol 39:1360-1367 (2001).

22 CLSI, Clinical and Laboratory Standards Institute Methods for dilution antimicrobial susceptibility tests for bacteria that grow aerobically. Approved 
standard, 8th ed. CLSI publication M07-A8. Clinical and Laboratory Standards Institute, Wayne, PA (2009).

23 Tsukatani T, Suenaga H, Shiga M, Noguchi K, Ishiyama M, Ezoe T, Matsumoto K, Comparison of the WST-8 colorimetric method and the CLSI broth microdilution method for susceptibility testing against drug-resistant bacteria. $J$ Microbiol Method 90:160-166 (2012).

24 Booth C, Fungal culture media. In J. R. Norris \& D. W. Ribbons (Eds.), Methods in microbiology (pp. 49-94). London and New York: Academic Press (1971).

25 Dikeman CL, Bauer LL, Flickinger EA, Fahey GCJr, Effects of stage of maturity and cooking on the chemical composition of select mushroom varieties. J Agric Food Chem 53:1130-1138 (2005).

26 Fürst P. Kuhn KS, Fish oil emulsions: what benefits can they bring? Clin Nutri 19:7-14 (2000).

27 Fang YZ, Yang S, Wu G, Free radicals, antioxidants, and nutrition. Nutrition 18: $872-879(2002)$.

28 Simopoulos AP, Omega-3 fatty acids in health and disease and in growth and development. Am J Clin Nutr 54:438-463 (1991).

29 Senter SD, Payne JA, Miller G, Anagnosakis SL, Comparison of total lipids, fatty acids sugars and non-volatile organic acids in nuts from four Castanea species. J Sci Food Agric 65:223-227(1994).

30 Künsch U, Scharer H, Conedera M, Sassella A, Jermini M, Jelmini G, Quality assessment of chestnut fruits. Acta Horticulturae 494:119-127 (1999).

31 Kok TMCM, Zwingman I, Moonen EJ, Schilderman PAEL, Rhijnsburger E, Haenen GRMM, Kleinjans JCS, Analysis of oxidative DNA damage after 
human dietary supplementation with linoleic acid. Food Chem Toxicol 41:351$358(2003)$.

32 Morrissey PA, Sheehy PJA, Gaynor P, Vitamin E. Am J Clin Nutr Bethesda 62:260-264 (1994).

33 Heinonen OP, Albanes D, Virtamo J, Tbaylor PR, Huttunen JK, Hartman AM, Haapakoski J, Malila N, Rautalahti M, Ripatti S, Maenpaa H, Teerenhovi L, Koss L, Virolainen M, Edwards BK, Prostate cancer and supplementation with alpha-tocopherol and beta-carotene: incidence and mortality in controlled trial. $J$ National Cancer Inst 90:440-446 (1998).

34 Devore EE, Grodstein F, van Rooij FJA, Hofman A, Stampfer M.J., Witteman JCM Breteler MMB, Dietary antioxidants and long-term risk of dementia. Arch Neurology 67:819-825 (2010).

35 Mangialasche F, Kivipelto M, Mecocci P, Rizzuto D, Palmer K, Winblad B, Fratiglioni, L, High plasma levels of vitamin E forms and reduced Alzheimer's disease risk in advanced age. J Alzheimer Disease 20:1029-1037 (2010).

36 Pace A, Giannarelli D, Galiè E, Savarese A, Carpano S, Giulia MD, Pozzi A, Silvani A, Gaviani P, Scaioli V, Jandolo B, Bove L, Cognetti F, Vitamin E neuroprotection for cisplatin neuropathy. Neurology 74:762-766 (2010).

37 Traber MG, Packer L, Vitamin E: beyond antioxidant function. Am J Clin Nutr 62:1501S-1509S (1995).

38 Luximon-Ramma A, Bahorun T, Crozier A, Antioxidant action and phenolic and vitamin C contents of common Mauritian exotic fruits. J Sci Food Agric 83:496$502(2003)$. 
39 Luximon-Ramma A, Bahorun T, Crozier A, Zbarsky V, Datla KK, Dexter DT, Aruoma OI, Characterization of the antioxidant functions of flavonoids and proanthocyanidins in Mauritian black teas. Food Res Int 38:357-367 2005).

40 Soobrattee MA, Neergheen VS, Luximon-Ramma A, Aruoma OI, Bahorun T, Phenolics as potential antioxidant therapeutic agents: mechanisms and actions. Mutation Research/Fundamental and Molecular Mechanisms of Mutagenicity 579:200-213 (2005). 
Table 1. Composition in nutrients expressed in dry weight basis (mean $\pm \mathrm{SD}$ ).

\begin{tabular}{|c|c|c|c|}
\hline & $\begin{array}{c}\text { Morchella conica } \\
\text { (Portugal) }\end{array}$ & $\begin{array}{c}\text { Morchella conica } \\
\text { (Serbia) }\end{array}$ & $\begin{array}{c}\text { Student's } t \text {-test } \\
p \text {-value }\end{array}$ \\
\hline Fat $\left(\mathrm{g} \mathrm{kg}^{-1}\right)$ & $28 \pm 1$ & $27 \pm 1$ & 0.025 \\
\hline Proteins $\left(\mathrm{g} \mathrm{kg}^{-1}\right)$ & $75 \pm 4$ & $101 \pm 3$ & 0.001 \\
\hline $\operatorname{Ash}\left(\mathrm{g} \mathrm{kg}^{-1}\right)$ & $146 \pm 3$ & $67 \pm 3$ & $<0.001$ \\
\hline Carbohydrates $\left(\mathrm{g} \mathrm{kg}^{-1}\right)$ & $750 \pm 4$ & $805 \pm 3$ & $<0.001$ \\
\hline Energy $\left(\mathrm{g} \mathrm{kg}^{-1}\right)$ & $3556 \pm 11$ & $3865 \pm 15$ & $<0.001$ \\
\hline Fructose $\left(\mathrm{g} \mathrm{kg}^{-1}\right)$ & $2.1 \pm 0.2$ & $2.1 \pm 0.04$ & 0.864 \\
\hline Mannitol $\left(\mathrm{g} \mathrm{kg}^{-1}\right)$ & $33 \pm 2$ & $45 \pm 1$ & 0.001 \\
\hline Trehalose $\left(\mathrm{g} \mathrm{kg}^{-1}\right)$ & $50 \pm 2$ & $49 \pm 1$ & 0.315 \\
\hline Total Sugars $\left(\mathrm{g} \mathrm{kg}^{-1}\right)$ & $85 \pm 4$ & $95 \pm 1$ & 0.022 \\
\hline C16:0 & $11 \pm 2$ & $10 \pm 1$ & 0.370 \\
\hline C18:0 & $2.4 \pm 0.2$ & $1.5 \pm 0.1$ & $<0.001$ \\
\hline $\mathrm{C} 18: \ln 9$ & $21 \pm 2$ & $19 \pm 1$ & 0.150 \\
\hline $\mathrm{C} 18: 2 \mathrm{n} 6$ & $63 \pm 4$ & $67 \pm 1$ & 0.077 \\
\hline SFA (relative percentage) & $14 \pm 2$ & $13 \pm 1$ & 0.053 \\
\hline MUFA (relative percentage) & $22 \pm 2$ & $20 \pm 1$ & 0.145 \\
\hline PUFA (relative percentage) & $64 \pm 4$ & $67 \pm 1$ & 0.093 \\
\hline$\alpha$-tocopherol $\left(\mu \mathrm{g} \mathrm{kg}^{-1}\right)$ & $62 \pm 8$ & $14 \pm 2$ & $<0.001$ \\
\hline$\beta$-tocopherol $\left(\mu \mathrm{g} \mathrm{kg}^{-1}\right)$ & $200 \pm 12$ & nd & - \\
\hline$\gamma$-tocopherol $\left(\mu \mathrm{g} \mathrm{kg}^{-1}\right)$ & nd & nd & - \\
\hline$\delta$-tocopherol $\left(\mu \mathrm{g} \mathrm{kg}^{-1}\right)$ & nd & $39 \pm 5$ & - \\
\hline Total tocopherols $\left(\mu \mathrm{g} \mathrm{kg}^{-1}\right)$ & $262 \pm 20$ & $53 \pm 7$ & $<0.001$ \\
\hline
\end{tabular}

nd- not detected.

Main fatty acids: C16:0 (Palmitic acid), C18:0 (Stearic acid), C18:1n9 (Oleic acid) and C18:2n6 (Linoleic acid); 20 more fatty acids were identified in trace amounts. SFASaturated fatty acids; MUFA- Monounsaturated fatty acids; PUFA- Polyunsaturated fatty acids. 
Table 2. Composition in non-nutrients expressed in dry weight basis (mean $\pm \mathrm{SD}$ ).

\begin{tabular}{lccc}
\hline & $\begin{array}{c}\text { Morchella conica } \\
\text { (Portugal) }\end{array}$ & $\begin{array}{c}\text { Morchella conica } \\
\text { (Serbia) }\end{array}$ & $\begin{array}{c}\text { Student's } t \text {-test } \\
\text {-value }\end{array}$ \\
\hline Oxalic acid $\left(\mathrm{g} \mathrm{kg}^{-1}\right)$ & $1.9 \pm 0.1$ & $0.5 \pm 0.1$ & $<0.001$ \\
Quinic acid $\left(\mathrm{g} \mathrm{kg}^{-1}\right)$ & $8.1 \pm 0.3$ & $8.8 \pm 0.4$ & 0.017 \\
Fumaric acid $\left(\mathrm{g} \mathrm{kg}^{-1}\right)$ & $5.61 \pm 0.02$ & $1.09 \pm 0.02$ & $<0.001$ \\
Total organic acids $\left(\mathrm{g} \mathrm{kg}^{-1}\right)$ & $15.6 \pm 0.3$ & $10.5 \pm 0.5$ & $<0.001$ \\
\hline Gallic acid $\left(\mathrm{mg} \mathrm{kg}^{-1}\right)$ & $\mathrm{nd}$ & $1.83 \pm 0.01$ & - \\
Protocatechuic acid $\left(\mathrm{mg} \mathrm{kg}^{-1}\right)$ & $20.8 \pm 0.1$ & $4.96 \pm 0.02$ & $<0.001$ \\
$p$-Hydroxybenzoic acid $\left(\mathrm{mg} \mathrm{kg}^{-1}\right)$ & $\mathrm{nd}$ & $55.2 \pm 0.4$ & - \\
$p$-Coumaric acid $\left(\mathrm{mg} \mathrm{kg}^{-1}\right)$ & $2.48 \pm 0.01$ & $2.15 \pm 0.01$ & 0.001 \\
Total phenolic compounds $\left(\mathrm{mg} \mathrm{kg}^{-1}\right)$ & $23.3 \pm 0.1$ & $64.1 \pm 0.3$ & $<0.001$ \\
Cinnamic acid $\left(\mathrm{mg} \mathrm{kg}^{-1}\right)$ & nd & $12.9 \pm 0.1$ & - \\
\hline nd- not detected & & &
\end{tabular}


Table 3. Antioxidant activity of the methanolic extracts (mean \pm SD).

\begin{tabular}{|c|c|c|c|c|}
\hline & Assay & $\begin{array}{c}\text { Morchella conica } \\
\text { (Portugal) }\end{array}$ & $\begin{array}{c}\text { Morchella conica } \\
\text { (Serbia) }\end{array}$ & $\begin{array}{c}\text { Student's } t \text {-test } \\
p \text {-value }\end{array}$ \\
\hline \multirow{2}{*}{ Reducing power } & $\begin{array}{l}\text { Folin-ciocalteu } \\
\text { (mg GAE g }{ }^{-1} \text { extract) }\end{array}$ & $32.8 \pm 1.1$ & $26.4 \pm 0.4$ & $<0.001$ \\
\hline & $\begin{array}{l}\text { Ferricyanide/Prussian blue } \\
\left(\mathrm{EC}_{50} ; \mathrm{mg} \mathrm{mL}^{-1}\right)\end{array}$ & $1.16 \pm 0.01$ & $1.88 \pm 0.06$ & $<0.001$ \\
\hline Radical scavenging activity & $\begin{array}{l}\text { DPPH scavenging activity } \\
\left(\mathrm{EC}_{50} ; \mathrm{mg} \mathrm{mL}^{-1}\right)\end{array}$ & $3.56 \pm 0.09$ & $9 \pm 2$ & $<0.001$ \\
\hline \multirow{2}{*}{ Lipid peroxidation inhibition } & $\begin{array}{l}\beta \text {-carotene/linoleate } \\
\left(\mathrm{EC}_{50} ; \mathrm{mg} \mathrm{mL}^{-1}\right)\end{array}$ & $2.5 \pm 0.4$ & $0.8 \pm 0.1$ & $<0.001$ \\
\hline & $\begin{array}{l}\text { TBARS } \\
\left(\mathrm{EC}_{50} ; \mathrm{mg} \mathrm{mL}^{-1}\right)\end{array}$ & $0.55 \pm 0.03$ & $0.3 \pm 0.1$ & $<0.001$ \\
\hline
\end{tabular}

Concerning the Folin-Ciocalteu assay, higher values mean higher reducing power; for the other assays, the results are presented in $\mathrm{EC}_{50}$ values, what means that higher values correspond to lower reducing power or antioxidant potential. $\mathrm{EC}_{50}$ : Extract concentration corresponding to $50 \%$ of antioxidant activity or 0.5 of absorbance for the Ferricyanide/Prussian blue assay. 
Table 4. Antibacterial and antifungal activities of the methanolic extracts and standard drugs $\left(\mathrm{mg} \mathrm{mL}^{-1}\right)(\mathrm{mean} \pm \mathrm{SD})$.

\begin{tabular}{|c|c|c|c|c|}
\hline Bacteria & $\begin{array}{c}\text { Morchella conica } \\
\text { (Portugal) } \\
\text { MIC/MBC }\end{array}$ & $\begin{array}{c}\text { Morchella conica } \\
\text { (Serbia) } \\
\text { MIC/MBC }\end{array}$ & $\begin{array}{l}\text { Streptomycin } \\
\text { MIC/MBC }\end{array}$ & $\begin{array}{l}\text { Ampicillin } \\
\text { MIC/MBC }\end{array}$ \\
\hline Staphylococcus aureus & $1.87 \pm 0.04^{\mathrm{c}} / 3.75 \pm 0.02^{\mathrm{b}}$ & $3.75 \pm 0.08^{\mathrm{d}} / 7.50 \pm 0.07^{\mathrm{c}}$ & $0.04 \pm 0.00^{\mathrm{a}} / 0.09 \pm 0.03^{\mathrm{a}}$ & $0.25 \pm 0.02^{\mathrm{b}} / 0.37 \pm 0.01^{\mathrm{a}}$ \\
\hline Bacillus cereus & $0.70 \pm 0.02^{\mathrm{c}} / 0.95 \pm 0.02^{\mathrm{c}}$ & $0.95 \pm 0.03^{\mathrm{d}} / 1.87 \pm 0.02^{\mathrm{d}}$ & $0.09 \pm 0.003^{\mathrm{a}} / 0.17 \pm 0.00^{\mathrm{a}}$ & $0.25 \pm 0.02^{\mathrm{b}} / 0.37 \pm 0.01^{\mathrm{b}}$ \\
\hline Micrococcus flavus & $1.87 \pm 0.04^{\mathrm{b}} / 3.75 \pm 0.05^{\mathrm{b}}$ & $7.5 \pm 0.10^{\mathrm{c}} / 15.0 \pm 0.0^{\mathrm{c}}$ & $0.17 \pm 0.01^{\mathrm{a}} / 0.34 \pm 0.01^{\mathrm{a}}$ & $0.25 \pm 0.00^{\mathrm{a}} / 0.37 \pm 0.01^{\mathrm{a}}$ \\
\hline Listeria monocytogenes & $3.75 \pm 0.08^{\mathrm{c}} / 7.5 \pm 0.02^{\mathrm{b}}$ & $3.75 \pm 0.05^{\mathrm{c}} / 7.50 \pm 0.01^{\mathrm{b}}$ & $0.17 \pm 0.007^{\mathrm{a}} / 0.34 \pm 0.00^{\mathrm{a}}$ & $0.37 \pm 0.007^{\mathrm{b}} / 0.49 \pm 0.01^{\mathrm{a}}$ \\
\hline Pseudomonas aeruginosa & $0.70 \pm 0.02^{\mathrm{b}} / 0.95 \pm 0.02^{\mathrm{b}}$ & $7.5 \pm 0.007^{\mathrm{c}} / 15.0 \pm 0.00^{\mathrm{d}}$ & $0.17 \pm 0.01^{\mathrm{a}} / 0.34 \pm 0.01^{\mathrm{a}}$ & $0.74 \pm 0.003^{\mathrm{b}} / 1.24 \pm 0.09^{\mathrm{c}}$ \\
\hline Salmonella typhimurium & $0.70 \pm 0.07^{\mathrm{c}} / 0.95 \pm 0.02^{\mathrm{b}}$ & $3.75 \pm 0.08^{\mathrm{d}} 7.50 \pm 0.10^{\mathrm{c}}$ & $0.17 \pm 0.007^{\mathrm{a}} / 0.34 \pm 0.007^{\mathrm{a}}$ & $0.37 \pm 0.00^{\mathrm{b}} / 0.49 \pm 0.01^{\mathrm{a}}$ \\
\hline Escherichia coli & $5.62 \pm 0.10^{\mathrm{b}} / 7.50 \pm 0.10^{\mathrm{b}}$ & $7.5 \pm 0.10^{\mathrm{c}} / 15.0 \pm 0.20^{\mathrm{c}}$ & $0.17 \pm 0.01^{\mathrm{a}} / 0.34 \pm 0.01^{\mathrm{a}}$ & $0.25 \pm 0.01^{\mathrm{a}} / 0.49 \pm 0.02^{\mathrm{a}}$ \\
\hline Enterobacter cloacae & $5.62 \pm 0.10^{\mathrm{b}} / 7.50 \pm 0.10^{\mathrm{b}}$ & $7.5 \pm 0.00^{\mathrm{c}} / 15.0 \pm 0.20^{\mathrm{c}}$ & $0.26 \pm 0.02^{\mathrm{a}} / 0.52 \pm 0.00^{\mathrm{a}}$ & $0.37 \pm 0.01^{\mathrm{a}} / 0.74 \pm 0.02^{\mathrm{a}}$ \\
\hline Fungi & $\begin{array}{c}\text { Morchella conica } \\
\text { (Portugal) } \\
\text { MIC/MFC }\end{array}$ & $\begin{array}{c}\text { Morchella conica } \\
\text { (Serbia) } \\
\text { MIC/MFC }\end{array}$ & $\begin{array}{l}\text { Bifonazole } \\
\text { MIC/MBC }\end{array}$ & $\begin{array}{l}\text { Ketoconazole } \\
\text { MIC/MBC }\end{array}$ \\
\hline Penicillium aurantiogriseum & $6.25 \pm 0.02^{\mathrm{b}} / 12.5 \pm 0.20^{\mathrm{b}}$ & $12.5 / \pm 0.20^{\mathrm{c}} / 25.00 \pm 0.30^{\mathrm{c}}$ & $0.15 \pm 0.02^{\mathrm{a}} / 0.20 \pm 0.00^{\mathrm{a}}$ & $0.20 \pm 0.00^{\mathrm{a}} / 0.50 \pm 0.02^{\mathrm{a}}$ \\
\hline Aspergillus versicolor & $6.25 \pm 0.08^{\mathrm{b}} / 6.25 \pm 0.08^{\mathrm{b}}$ & $12.5 \pm 0.20^{\mathrm{c}} / 12.5 \pm 0.20^{\mathrm{c}}$ & $0.10 \pm 0.00^{\mathrm{a}} / 0.20 \pm 0.00^{\mathrm{a}}$ & $0.20 \pm 0.02^{\mathrm{a}} / 0.50 \pm 0.02^{\mathrm{a}}$ \\
\hline Aspergillus ochraceus & $3.12 \pm 0.04^{\mathrm{c}} / 6.25 \pm 0.08^{\mathrm{c}}$ & $12.5 \pm 0.20^{\mathrm{d}} / 12.5 \pm 0.00^{\mathrm{d}}$ & $0.15 \pm 0.02^{\mathrm{a}} / 0.20 \pm 0.02^{\mathrm{a}}$ & $1.50 \pm 0.00^{\mathrm{b}} / 2.00 \pm 0.10^{\mathrm{b}}$ \\
\hline Aspergillus niger & $1.56 \pm 0.01^{b} / 3.12 \pm 0.04^{c}$ & $6.25 \pm 0.08^{\mathrm{c}} / 6.25 \pm 0.08^{\mathrm{d}}$ & $0.15 \pm 0.00^{\mathrm{a}} / 0.20 \pm 0.00^{\mathrm{a}}$ & $0.20 \pm 0.01^{\mathrm{a}} / 0.50 \pm 0.02^{\mathrm{b}}$ \\
\hline Trichoderma viride & $0.78 \pm 0.007^{\mathrm{b}} / 1.56 \pm 0.00^{\mathrm{c}}$ & 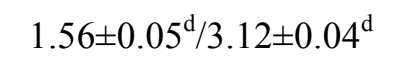 & $0.15 \pm 0.00^{\mathrm{a}} / 0.20 \pm 0.01^{\mathrm{a}}$ & $1.00 \pm 0.10^{\mathrm{c}} / 1.00 \pm 0.10^{\mathrm{b}}$ \\
\hline
\end{tabular}

MIC- minimum inhibitory concentration; MBC- minimum bactericidal concentration.

In each line different letters mean significant differences $(p<0.05)$. 


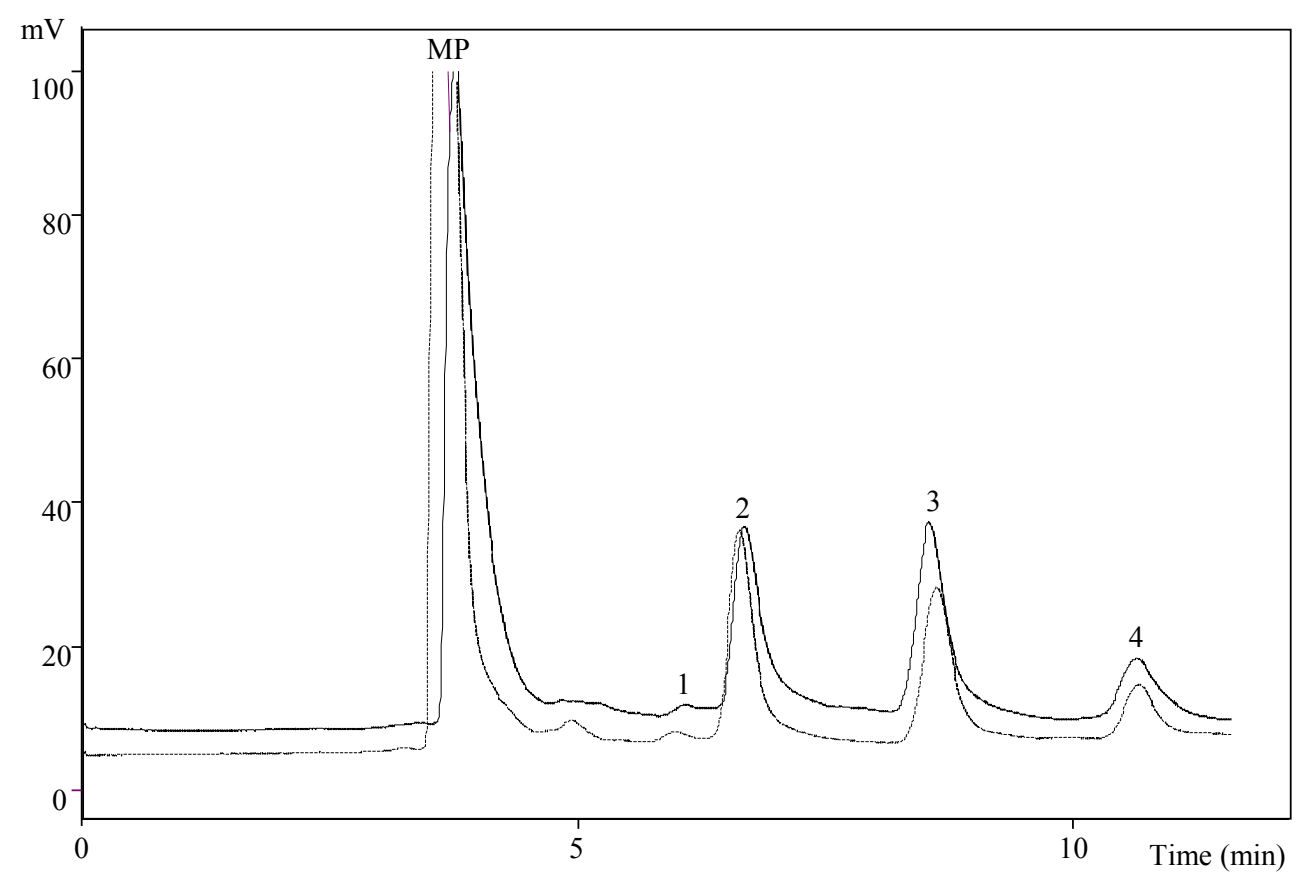

A

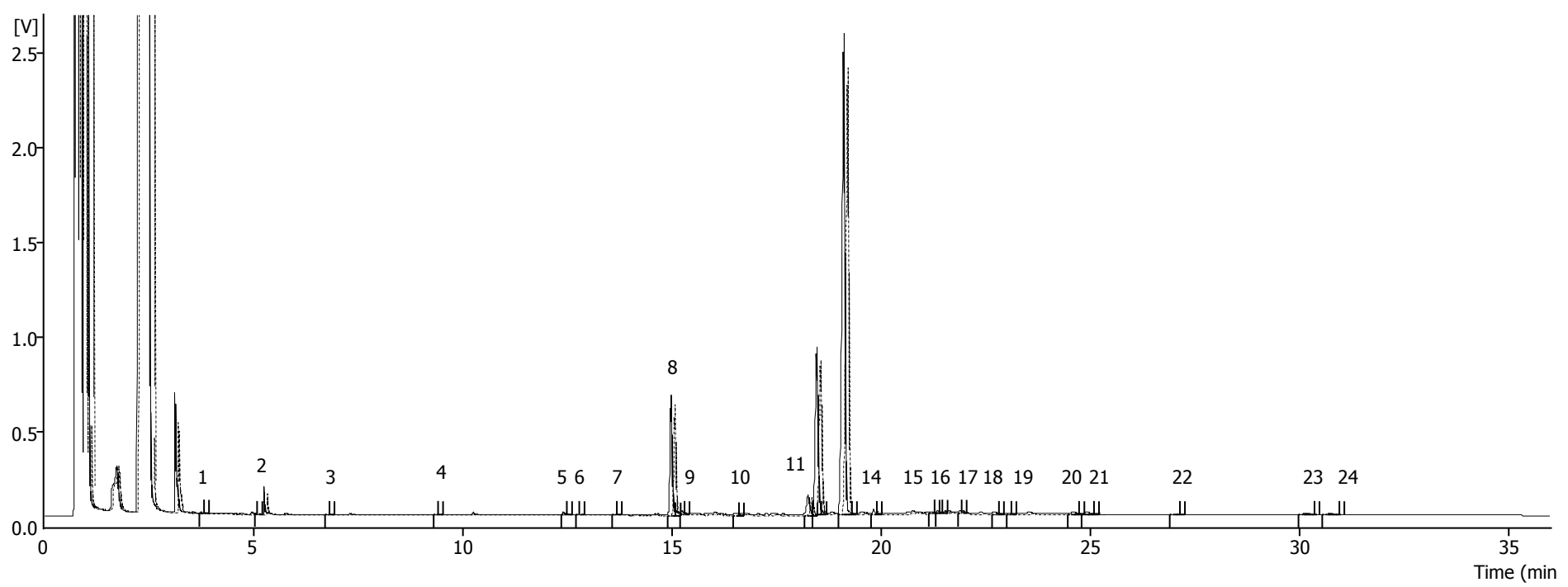

B 


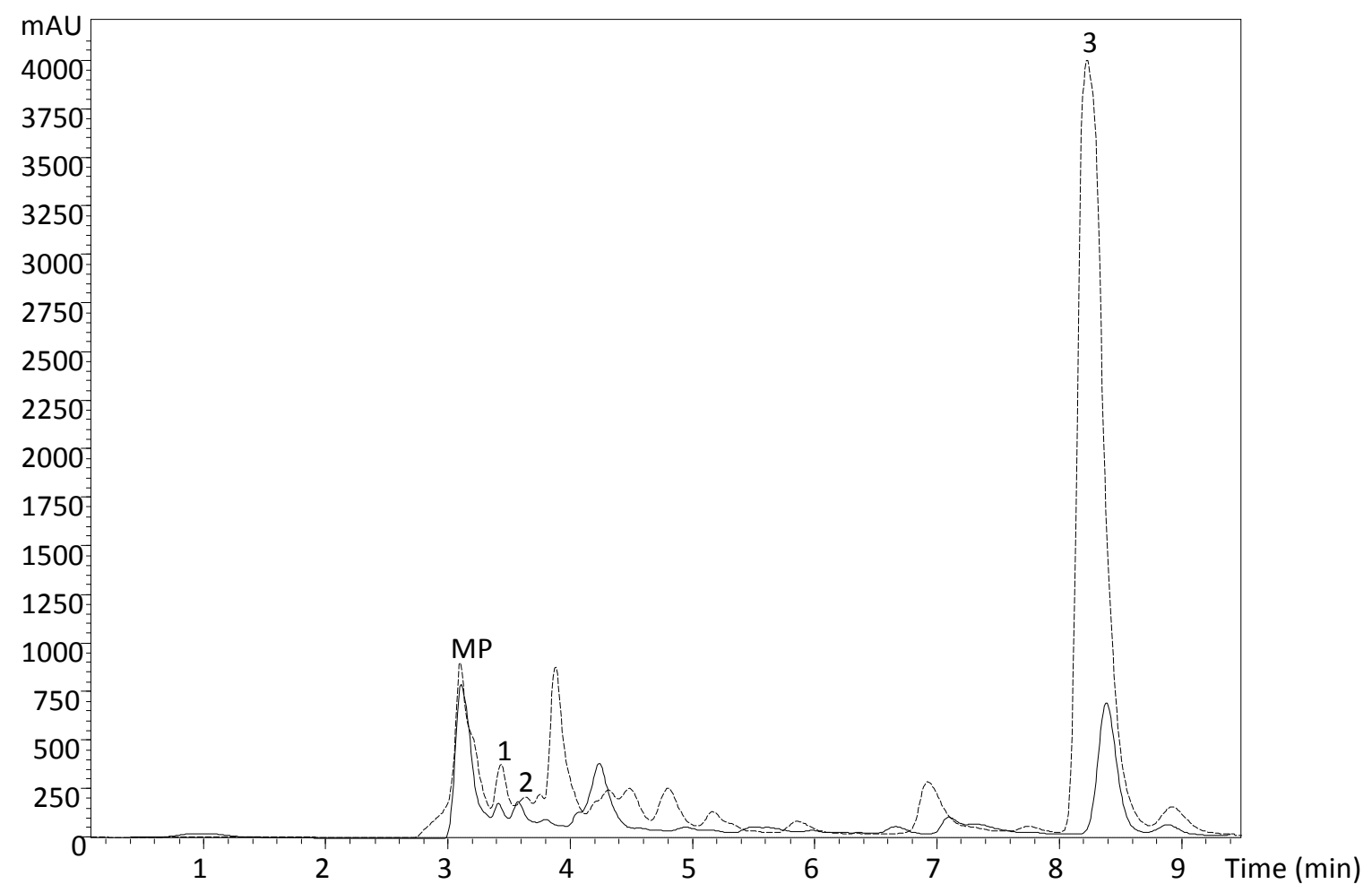

C

Figure 1. Individual profile of M. conica from Portugal (---) and Serbia (-) in (A) sugars: 1- fructose, 2- mannitol, 3- trehalose; (B) fatty acids: 1- caproic acid (C6:0); 2caprylic acid (C8:0); 3- capric acid (C10:0); 4- lauric acid (C12:0); 5- myristic acid (C14:0); 6- myristoleic acid (C14:1); 7- pentadecanoic acid (C15:0); 8-palmitic acid (C16:0); 9- palmitoleic acid (C16:1); 10- heptadecanoic acid (C17:0); 11-stearic acid (C18:0); 12- oleic acid (C18:1n9c); 13- linoleic acid (C18:2n6c); 14- $\alpha$-linolenic acid (C18:3n3c); 15-arachidic acid (C20:0); 16-eicosenoic acid (C20:1c); 17- cis-11,14eicosadienoic acid (C20:2c); 18- cis-11, 14, 17-eicosatrienoic acid and heneicosanoic acid (C20:3n3+C21:0); 19- cis-5,8,11,14,17-eicosapentaenoic acid (C20:5n3); 20behenic acid (C22:0); 21 - Eicosenoic acid (C22:1n9); 22- tricosanoic acid (C23:0); 23lignoceric acid (C24:0); 24- nervonic acid (C24:1) and (C) organic acids: 1- oxalic acid, 2- quinic acid, 3- fumaric acid. MP- mobile phase. 